\title{
Identification of Dominant Factors Influencing Non- engineering Students of Politeknik Negeri Padang Intentions as Entrepreneur
}

\author{
Yudhytia Wimeina ${ }^{1}$, Rafidola Mareta Riesa ${ }^{2}$, Alhapen R. Chandra ${ }^{3}$ \\ \{yudhytia@pnp.ac.id ${ }^{1}$,rafidola@pnp.ac.id², alhapen.chandra@gmail.com ${ }^{3}$ \} \\ 1,2,3Politeknik Negeri Padang, Kampus Limau Manis, Padang, Sumatera Barat
}

\begin{abstract}
To be an advance nation, it takes $14 \%$ of one country citizen as entrepreneur, while curently, Indonesia only has 3,1\% entrepreneur of its citizen. Therefore, the government promotes entrepreneurial program for students especially those in higher education. Through this research, the factors that might influencing students of Politeknik Negeri Padang, especially non-engineering students, intention as entrepreneur is identified. By distributing questionnaires which developed based on planned behavior theory, data was collected and processed by utilizing structured equational model. It resulted that there are variables that positively influencing intention as entrepreneurial attitude, and others, subjective norms and behavior control are not confirmed.
\end{abstract}

Keywords: entrepreneurial, students entrepreneurship, entrepreneurial intention

\section{Introduction}

Referring to Statistic Official News number 42/05/Th. XXI, issued by Central Bureau of Statistic of Indonesia on May 7th, 2018, there were 6,870,000 unemployed Indonesian from $193,550.000$ workforce figure, or $3.55 \%$ of Indonesian workforce was unemployed. From the figure of Indonesian workforce, there were also $15,610,000$ or $8,07 \%$ that will be added to 2019 unemployment figure once they graduates [1]. This figures will be an issue for Indonesia governent and weighing on the economy if those figure were not able to be absorb.

To encounter the situation, Indonesia government has promoted programs and issuing regulations such as government regulation (PP) No. 60 of 2013, No. 41 of 2011 as well as ministry regulation (PERMENPORA) No. 0944 of 2015 to boost entrepreneurial. Those regulation also revealing government concern of Indonesia entrepreneurial rate positioned below its neighboring countries. To be recognized as an advance nation, the figure of entrepeneur of a country should be $14 \%$ of its total citizen, unfortunately, Indonesia just have $3.1 \%$ [2], which is lower compare to Singapore, with 7\% and Malaysia, 5\% [3].

Economist and experts has suggested that entrepreneurship is an important factor for economic growth. Trough unique and creative effort, entrepreneurship is able to increase productivity, inovation and economic growth [4]. Entrepreneurship also empowered people to exploring the opportunities in order to enhance their social condition and the quality of existence [5]. In addition, entrepreneurship promotes employment opportunities, economic and technology growth, social transformation, as well as wellness and prosperity [6]. 
According to the European Commission (2013), entrepreneurship rate might also be improved trough education. Entrepreneurship education or lesson might motivate students to form their knowledge of entrepreneurial, as well as their skills and attitude [7]. Prior to this, Liñan dan Chen (2011) already stated that entrepreneurship education is one of the factor to increase entrepreneur attitude [8]. Therefore, beside issuing policies, Indonesia government also developed entrepreneur as a learning subject especialy for higher education, and also being regulated within government regulation number 17 of 2010. In this regulation it is mentioned that one of the objectives of higher education providence is to shaping up critical, creative, innovative, independent, confident, as well as entrepreneurial spirited individual [9].

Consequently, Politeknik Negeri Padang, as a state vocational higher education institution, based on the regulation has developed entrepreneurial curiculumn that being conveyed in various forms, from classroom learning process, public lecture, as well as facilitates students with other platforms such as entrepreneurial competition and scholarship. Therefore, this research is aimed to find and test the relevant variables influences toward Politeknik Negeri Padang non-engineering student intention to be an entrepreneur. Variables that being tested in this research were adopted from the theory of planned behavior which cover entrepreneurial attitude, subjective norm, and behavior control [10].

Entrepreneurial intention is the key to understand the process of entrepreneurship, and the best behavior predictor in forecasting the process of business creation [11]. A business creation is most likely impossible without any intention to do so [12]. Meanwhile, entrepreneurial attitude is a degree of individual positivity in finding and starting a new business, and significantly relates to entrepreneurial intention [13]. Furthermore, subjective norm is social force to perform or act in certain way, and also significantly relates to entrepreneurial intention [14]. In addition, Maes et al., (2014) suggested behavior control is something that makes an individual feels the convenience and difficulties as an entrepreneur [15].

\section{Method}

As mentioned previously, this research is refering to the model of planned behaviour as its theoritical framework, since according to Obschonka et. al.,(2015) this model is suitable to implement within academic environment [16], therefore, the research model is as follow; 


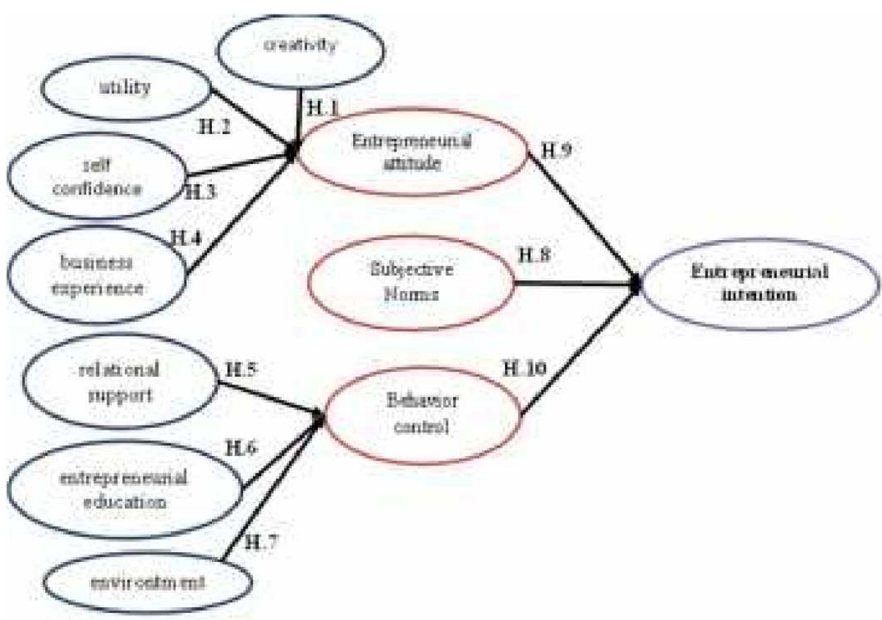

Fig. 1. Research Framework

Based on the above framework, a questionnaire then developed and distributed to respondents those are nonengineering students of Politeknik Negeri Padang. The questionnaire was developed in regards to respond to the following hypothesis:

1. Creativity is positively influencing students entrepreneurial attitude

2. Utility is positively influencing students entrepreneurial attitude

3. Self confidence is positively influencing students entrepreneurial attitude

4. Business experience is positively influencing students entrepreneurial attitude

5. Relational support is positively influencing students behavior control of entrepreneurship

6. Entrepreneurial education is positively influencing students behavior control of entrepreneurship

7. Environtment is positively influencing students behavior control of entrepreneurship

8. Subjective norm is positively impacting the entrepreneurial intention

9. Entrepreneurial attitude is positively impacting the entrepreneurial intention

10. Behavior control of entrepreneurship is positively impacting the entrepreneurial intention

There were 78 non-engineering students of Politeknik Negeri Padang participated as respondents of this research, where their feedback on questionnaire then being processed by utilizing structured equational model of partial least square regression (PLS). This method being used since it is able to construct predictive model upon numerous colinear factors, and also practical in limitizing the factors measured [17].

\section{Result and Discussion}

Previously mentioned that there were 78 non-engineering student participated to this research, in which $36 \%$ are those majoring in accounting, $31 \%$ from commerce administration, and 33\% from english department, in addition, from 78 respondents figure, $62 \%$ are female and the rest $38 \%$ are male. Moreover, 53 students out of 78 or $68 \%$ of the respondents only spend 
not more than Rp. 500.000 per month for their transportation and meals expense, and 33\% out of 78 are scholarship beneficiaries.

From data collected, the reliability of the indicators utilized within the questionnaire is tested to make sure that the indicators are consistent to be used in other study or research. Composite reliability $(\rho c)$ and Cronbach's alpha $(\alpha)$ resulted from the PLS are used to assess the reliability of the questionnaire used. The result are shown on the following table;

Table 1. Construct Reliability

\begin{tabular}{|l|c|c|}
\hline \multicolumn{1}{|c|}{ Construct } & $\begin{array}{c}\text { Composite Reliability } \\
(\boldsymbol{p})\end{array}$ & $\begin{array}{c}\text { Cronbach's alpha } \\
(\boldsymbol{\alpha})\end{array}$ \\
\hline Greativity & 0.8209 & 0.7637 \\
\hline Utility & 0.8377 & 0.7570 \\
\hline Self Confident & 0.7380 & 0.5821 \\
\hline Business Experience & 0.8151 & 0.5533 \\
\hline Relational Support & 0.8278 & 0.7440 \\
\hline Entrepreneurial Education & 0.7340 & 0.7366 \\
\hline Envircument & 0.8309 & 0.7874 \\
\hline Subjective Norms & 0.8278 & 0.7083 \\
\hline Entrepreneurial Attitude & 0.8889 & 0.8332 \\
\hline Behavior Control & 0.9027 & 0.8766 \\
\hline Intention & 0.9029 & 0.8564 \\
\hline
\end{tabular}

Source: dataprocessed

Based on the data shown on the table 1 , most of the construct or variable tested has composite reliability value above 0.8 , and there are two variables, self confidence and entrepreneurial education, has the value of 0.7 . The ideal value of composite reliability is 0.8 , and 0.7 is the minimum value accepted, therefore the indicators are reliable based on the standard of composite reliability. In accord to composite reliability, cronbach's alpha of the indicators are accepted.. Aligned with reliability test, the validity of instrument utilized also tested to see its accuracy. To assess the validity, in this research the Average Variance Extracted is utilized, and the result shown on the following tabel;

Table 2. Construct Validity

\begin{tabular}{|l|c|}
\hline \multicolumn{1}{|c|}{ Construct } & $\begin{array}{c}\text { Average Variance Extracted } \\
\text { (AVE) }\end{array}$ \\
\hline Creativity & 0.5428 \\
\hline Utility & 0.5149 \\
\hline Self Confident & 0.3700 \\
\hline Business Experience & 0.6887 \\
\hline Relational Support & 0.4941 \\
\hline Entrepreneurial Education & 0.4571 \\
\hline Environment & 0.4537 \\
\hline Subjective Norms & 0.5104 \\
\hline Entrepteneurial Attitude & 0.6667 \\
\hline Behavior Control & 0.5170 \\
\hline Intenticn & 0.6997 \\
\hline
\end{tabular}

Source: data processed 
Reliability and validity that being tested for the indicators of this research model were part of outer model, then the structural or inner model of this research is processed in regards to test the hypothesis, the value are shown on the following tabel:

Table 3. Hypothesis Test

\begin{tabular}{|c|c|c|}
\hline Effect & f2 & T - Value \\
\hline Creativity $\rightarrow$ Attitude & 0.0055 & 0.5235 \\
\hline Creativity $\rightarrow$ Intention & & 0.4966 \\
\hline Utility $\rightarrow$ Attitude & 0.3463 & 5.7667 \\
\hline Utility $\rightarrow$ Intention & & 3.3477 \\
\hline Self Confidence $\rightarrow$ Attitude & 0.0475 & 1.7825 \\
\hline Self Confidence $\rightarrow$ Intention & & 1.6204 \\
\hline Business Experience $\rightarrow$ Attitude & 0.0221 & 1.5719 \\
\hline Business Experience $\rightarrow$ Intention & & 1.3991 \\
\hline Relational Support $\rightarrow$ Behavior Control & 0.1479 & 2.8400 \\
\hline Relational Support $\rightarrow$ Intention & & 1.2536 \\
\hline Entrepreneurial Education $\rightarrow$ Behaviour Control & 0.0114 & -0.6339 \\
\hline Entrepreneurial Education $\rightarrow$ Intention & & -0.5600 \\
\hline Environment $\rightarrow$ Behavior Control & 0.2576 & 4.2982 \\
\hline Environment $\rightarrow$ Intention & & 1.3646 \\
\hline Attitude $\rightarrow$ Intention & 0.2100 & 4.1331 \\
\hline Subjective Norms $\rightarrow$ Intention & 0.0403 & 1.8698 \\
\hline Behavior Control $\rightarrow$ Intention & 0.1933 & 1.4966 \\
\hline
\end{tabular}

Source: data processed

From table 3, we can see the value of $\mathrm{f}^{2}$ which represent the degree of significance of the relation within model structured [18]. The value of $\mathrm{f}^{2}$ are varies, when the value of $\mathrm{f}^{2}$ is lower than 0.02 it means the predictor variable has a low impact to the model structured, and if it is 0.15 and up, means the predictor variable has moderate impact, and 0.35 and up means strong impact. Therefore, creativity towards attitude, entrepreneurial education towards behavioral control, and subjective norm towards intention are has low impact, since their $\mathrm{f}^{2}$ are less than 0.02. Meanwhile, self confidence and business experience towards attitude, together with relational support and environtment towards behavior control, as well as attitude to intention are contributing sufficient or moderate impact. Furthuremore, utility is the variable that impacting strongly to attitude.

In align with $\mathrm{f}^{2}$, the $\mathrm{t}$-value also shows simmilar results, where utility towards attitude has the greater number of tvalue. If the t-value is greater than 1.96 means there is a positive or significant relations amongs the variables. Besides utility towards attitude, utility towards 
intention, relational support and environment to behavior control, and attitude towards intention are also has positive or significant relations. The rest of other relations based on the tvalue were not positively or significantly relates. Therefore, it can be concluded that only hypothesis 2,3 , $4,5,7,9$, and 10 that able to be accepted based on the result of $f^{2}$ and t-value.

\section{Conclusion}

Trough this research, the hypothesis of utility, self confidence, and business experience are positively influencing students entrepreneurial attitude, relational support and environment are influencing students behavior control, and, entrepreneurial attitude and behavior control is positively impacting the entrepreneurial intention were accepted. Meanhile the hypothesis of creativity positively influencing students entrepreneurial attitude, entrepreneurial education positively influencing behavior control, as well as subjective norms and behavior control are positively influencing entrepreneurial intention were not accepted or confirmed on this research.

\section{References}

[1] N. Midayanti, “Keadaan Ketenagakerjaan Indonesia Februari 2018," Badan Pusat Statistik, no. 42, Jakarta, pp. 1-16, 07-May-2018.

[2] D. J. Akhir, "Syarat Jadi Negara Maju: Jumlah Pengusaha 14\% dari Rasio Penduduk," okezone.com, $2019 . \quad$ [Online]. Available: https://economy.okezone.com/read/2019/04/09/320/2040896/. [Accessed: 09-Apr2019].

[3] B. P. Siregar, "Jumlah Pengusaha Indonesia Masih Tertinggal dari Singapura," 2018. [Online]. Available: https://www.wartaekonomi.co.id/read204928/jumlah-pengusahaindonesia-masih-tertinggal-darisingapura.html.

[4] N. Gennaioli, R. La Porta, F. Lopez-De-Silanes, and A. Shleifer, "Human Capital and Regional Development," Cambridge, 2011.

[5] G. T. Lumpkin, L. Steier, and M. Wright, "Globalization of Social Entrepreneurship Opportunities,” Strateg. Entrep. J., vol. 2, pp. 117-131, 2008.

[6] A. Bhidé, "The Origin and Evolution of New Businesses.," in Academy of Management Executive, New York: The Oxford University Press, 1999, pp. 1-197.

[7] European Commission, Entreprenuership Education: A Guide for Educators, no. June. Brussels: Bruxeless, 2013.

[8] F. Liñán, G. Nabi, and N. Krueger, "Bristish and Spanish Entrepreneurial Intensions: A Comparative Study," Rev. Econ. Mund., vol. 33, pp. 73-103, 2013.

[9] "Peraturan Pemerintah Republik Indonesia Nomor 17 Tahun 2010 Tentang Pengelolaan dan Penyelenggaraan Pendidikan.” Jakarta, Indonesia, pp. 1-215, 2010.

[10] Icek Ajzen, “Atttudes, Personality and Behavior," International Journal of Strategic Innovative Marketing, vol. 3. p. 117, 2005.

[11] N. F. Krueger, M. D. Reilly, and A. L. Carsrud, "Competing models of entrepreneurial intentions," J. Bus. Ventur., vol. 15, no. 5, pp. 411-432, 2000.

[12] O. O. Olakitan and A. P. Ayobami, "Entrepreneurial Intentions: A Theoretical Framework," J. Manag. Corp. Gov., vol. 2, no. 4, pp. 132-148, 2010.

[13] F. Liñán, J. C. Rodríguez-Cohard, and J. M. Rueda-Cantuche, "Factors affecting entrepreneurial intention levels: A role for education," Int. Entrep. Manag. J., vol. 7, no. 2, pp. 195-218, 2011.

[14] M. J. Malebana, "Entrepreneurial Intentions and Entrepreneurial Motivation of South 
African Rural University Students," J. Econ. Behav. Stud., vol. 6, no. 9, pp. 709-726, 2014.

[15] J. Maes, H. Leroy, and L. Sels, "Gender differences in entrepreneurial intentions: A TPB multi-group analysis at factor and indicator level," Eur. Manag. J., vol. 32, no. 5, pp. 784-794, 2014.

[16] M. Obschonka, R. K. Silbereisen, U. Cantner, and M. Goethner, "Entrepreneurial SelfIdentity: Predictors and Effects Within the Theory of Planned Behavior Framework," $J$. Bus. Psychol., vol. 30, no. 4, pp. 773-794, 2015.

[17] R. D. Tobias, “An Introduction to Partial Least Squares Regression,” Eur. Addict. Res., vol. 4, no. 4, pp. 144-149, 1998.

[18] A. Hidayat, "PLS SEM: Pengukuran Kecocokan Model (Inner dan Outer)," www.statistikian.com. [Online]. Available: https:/www.statistikian.com/2018/08/plssem-pengukuran-kecocokan-model-inner-dan-outer.html. [Accessed: 25-Oct-2019]. 